\title{
A new finishing process of cotton fabric
}

\section{REZUMAT - ABSTRACT}

\section{Un nou proces de finisare a țesăturilor din bumbac}

Responsabilitățile ecologice și economice au dus la căutarea aplicațiilor de materiale alternative atât în sectorul textil, cât și în alte sectoare. Tehnologia sol-gel este una dintre aceste aplicații cu multiple avantaje, cum ar fi prelucrarea la temperaturi scăzute și asigurarea formei și a formatului produsului dorit.

În acest studiu, probele de țesătură din 100\% bumbac au fost prelucrate prin utilizarea tehnicii de imprimare cu pigmenți cu piatră ponce naturală, cu silice amorfă și colemanit, iar procesul de fixare prin imprimare a fost realizat prin metoda de depunere sol-gel.

Tratamentul sol-gel a fost efectuat cu catalizator basic în funcție de potențialul zeta al materialelor sub formă de particule solide utilizate. După noul proces creat, au fost analizate morfologiile de suprafață, analiza punctului EDS și analiza FT-IR a tuturor probelor de țesături. În plus, au fost investigate proprietățile țesăturilor, cum ar fi rezistența, protecția UV, permeabilitatea la aer, permeabilitatea la apă, rezistența la abraziune, inflamabilitatea.

Rezultatele analizei de suprafață au demonstrat transferul componentelor chimice ale materialelor naturale pe probele de țesături. S-a dovedit că toate probele de țesături de bumbac au un grad ridicat de rezistență, protecție UV, inflamabilitate, rezistență ridicată la abraziune și o permeabilitate scăzută la aer. Interpretarea tuturor rezultatelor analizelor și rezultatelor obținute au fost, de asemenea, efectuate statistic.

Potrivit rezultatelor studiului, a fost creată o fază de prelucrare ecologică, care permite un cost redus de energie și o utilizare scăzută de substanțe chimice la temperature scăzute.

Cuvinte-cheie: piatră ponce, silice amorfă, colemanit, metodă sol-gel, țesătură din bumbac

\section{A new finishing process of cotton fabrics}

Ecological and economic responsibilities have led to the search for alternative material applications in the textile sector as well as in all sectors. Sol-gel technology is one of these applications with advantages such as realization under low temperatures and enabling the desired product shape and format.

In this study, the samples of $100 \%$ cotton fabric have been processed by using pigment printing technique with natural pumice, amorphous silica and colemanite materials and printing fixation process has been performed by using the sol gel coating method.

The sol gel treatment has been carried out with basic catalyst according to the zeta potentials of the solid particulate materials used. After the new created process, surface morphologies, EDS point analysis and F-TIR analysis of all fabric samples have been performed. In addition, the properties such as strength, UV protection, air permeability, water permeability, abrasion resistance, flammability of all fabrics have been investigated.

The results of surface analysis have proven that the chemical components of the natural materials are transferred to the fabric samples. It has been proven by the test results that all cotton fabric samples are given high strength, UV protection, flammability, high abrasion resistance and low air permeability. Interpretation of all the analysis and obtained test results has been also made statistically.

According to the study results, ecofriendly process step has been created that allows low energy cost and low chemical usage under low temperatures.

Key words: pumice, amorphous silica, colemanite, sol gel method, cotton fabric

\section{INTRODUCTION}

Today's ecological and economic responsibilities are directly affecting all stakeholders operating in the textile sector as well as in other sectors. At the same time, technological developments have led to changes in the expected characteristics of textile materials and development of different perspectives on material applications.

Especially in recent years, instead of classical methods, it is preferred to use environmentally friendly and natural applications which allow lower cost, and energy use. This situation leads us to discussion of the classical processes aimed at achieving optimum use characteristics and benefit from textile products. Especially multifunctional textile products, approach the market share of conventional textile products gradually, and increasingly become preferred due to its high value added, different and attractive properties. For this reason, scientific researches on textiles are gradually shifting to different directions and investigating different application fields.

In recent studies on textile finishing processes, the use of the sol gel method has been particularly striking in alternative application methods. Properties and advantages of the chemical materials used by the sol 
gel method can be transferred to the fabric. Using the sol gel method makes it is possible to improve the fastness properties, the physical and chemical properties and the functional properties of the fabrics.

In the 1970s, the formation of monolithic inorganic jellies at low temperatures and conversion to glass materials brought the sol-gel method to the agenda [1]. The fact that the sol gel method can be carried out at low temperatures and the ability to handle the products in the desired shapes and formats make this method increasingly used by different scientific disciplines and engineering fields [2-3]. It is the front plan to investigate the usability of the sol gel method instead of different processes, especially in the scientific studies carried out in textile field.

Basically, sol gel method goes through this process: A metal alkoxide or metal salt are used within an acid/base-catalyzed suitable solvent as a precursor. Then, hydrolysis and condensation reactions occur consequently.

The factors affecting the sol gel reaction are $\mathrm{pH}$, type and concentration of catalyst, type of solvent, type and structure of precursor, and temperature.

The aim of this study is to develop a new process that allows for the combined use of pigment printing and sol-gel technology using amorphous silica, colemanite and pumice, which are all provided by natural means [4]. It is aimed to develop the physical properties of cotton fabrics with the new process step created. Furthermore, thanks to the new process step, the fixing of the printing paddle has been carried out using sol gel technology instead of using of auxiliary chemicals (binder etc.); thus, ensuring the use of less chemical as possible.

\section{MATERIALS AND METHODS}

\section{Materials}

Scoured and bleached $100 \%$ plain weave cotton fabric (weight $284 \mathrm{~g} / \mathrm{m}^{2}, 38 \mathrm{picks} / \mathrm{cm}, 21$ ends $/ \mathrm{cm}$ ) has been used in this research. In preparing the sol gel solution; ethanol $\left(\mathrm{C}_{2} \mathrm{H}_{5} \mathrm{OH}, 96 \%\right.$, Merck, Germany) and distilled water ( $\mathrm{pH} 7$, conductivity $0,0182 \mathrm{mS} / \mathrm{cm}$, $25^{\circ} \mathrm{C}$ ) have been used as solvent. $0.1 \mathrm{~N}$ sodium hydroxide $(\mathrm{NaOH}, 100 \%$, pellet, Sigma-Aldrich, Germany) has been used as the $\mathrm{pH}$ controller in the basic hydrolysis process. TEOS $\left(\mathrm{Si}\left(\mathrm{OC}_{2} \mathrm{H}_{5}\right)_{4}, \% 98\right.$, Sigma-Aldrich, Germany)metal alkoxy has been used as a precursor for sol gel solution.

In pumice, which is one of the rock types formed after acidic and basic volcanic activities, macro and micro scale pores are formed due to abrupt abandonment of the gases of structure during the formation and sudden cooling [4-8]. Due to the structure of micropores, which are usually interconnected, the pumice has very high thermal and sound insulation properties [4-5, 7, 9]. The hardness of the pumice rock is 5-6 according to the Mohs scale and chemically has up to $75 \%$ silica content.

Amorphous silica; volcanic and hydrothermal systems are sedimentary rocks with a generally white color, formed as silica sediments on the surface as a result of cooling off the surface and reaching saturation, as well as underground veins near neutral chlorinated waters, with fluids containing colloidal silica particles having a certain temperature and balance in solution [4, 10, 11].

Amorphous silica is in a structure that has free oxygen bonds due to the complete dissociation of Si-O bonds in spite of melting after $1730^{\circ} \mathrm{C}$. Through this feature; amorphous silica exhibits a low thermal expansion coefficient and is an important material for areas where thermal shock is required or where temperature changes require dimensional stability [12-13]. In addition, amorphous silica is an ideal refractive optical material due to its resistance to ultraviolet rays.

Boron is an element commonly found on earth. It is know that there are 230 kinds of boron element, which has boron oxide $\left(\mathrm{B}_{2} \mathrm{O}_{3}\right)$ in different proportions, in nature [14]. Colemaniteis the most commonly found boron minerals. Colemanite is a boron compound with crystallization properties in the monoclinic system. Colemanite is a primary boron derivative containing silica, calcium, boron, magnesium, iron and potassium oxides and having $50.8 \% \mathrm{~B}_{2} \mathrm{O}_{3}$ in its structure.

In this study, pumice was obtained from Isparta Gelincik region, amorphous silica from Keçiborlulsparta and colemanite from ETI Mining Corp. of Bigadiç Balıkesir. All materials were sieved through number 200 sieve with a diameter of $0,076 \mathrm{~mm}$. The physical and chemical compositions of materials are shown as in table 1.

Table 1

\begin{tabular}{|c|c|c|c|c|}
\hline \multicolumn{5}{|c|}{$\begin{array}{l}\text { THE PHYSICAL AND CHEMICAL COMPOSITION } \\
\text { OF MATERIALS }\end{array}$} \\
\hline Ingredients & Unit & Pumice & $\begin{array}{l}\text { Amorphous } \\
\text { Silica }\end{array}$ & Colemanite \\
\hline $\mathrm{B}_{2} \mathrm{O}_{3}$ & $\%$ & - & - & 40.00 \\
\hline $\mathrm{CaO}$ & $\%$ & 4.68 & 0.31 & 27.00 \\
\hline $\mathrm{SiO}_{2}$ & $\%$ & 60.50 & 92.48 & $4.00-6.50$ \\
\hline $\mathrm{SO}_{4}$ & $\%$ & - & - & 0,60 \\
\hline As & $\mathrm{ppm}$ & - & - & 35 \\
\hline $\mathrm{Fe}_{2} \mathrm{O}_{3}$ & $\%$ & 3.38 & 0,09 & 0.08 \\
\hline $\mathrm{Al}_{2} \mathrm{O}_{3}$ & $\%$ & 17.15 & 2.60 & 0.40 \\
\hline $\mathrm{MgO}$ & $\%$ & 2.09 & - & 3.00 \\
\hline $\mathrm{SrO}$ & $\%$ & - & - & 1.50 \\
\hline $\mathrm{Na}_{2} \mathrm{O}$ & $\%$ & 4.30 & 1.08 & 0.35 \\
\hline $\mathrm{SO}_{3}$ & $\%$ & 0.16 & 0.09 & - \\
\hline $\mathrm{K}_{2} \mathrm{O}$ & $\%$ & 4.54 & 0.04 & - \\
\hline $\mathrm{TiO}_{2}$ & $\%$ & 0.41 & 1.34 & - \\
\hline
\end{tabular}

Tubivis VP 681 (ammonium salt of anionic carboxylic acid derivate, CHT, Turkey) as a synthetic thickener and Tubiprint Fixer RE (nonionic melamine formaldehyde derivative, $\mathrm{CHT}$, Turkey) as a fixerer have been 
used to prepare pumice and colemanite added printing paste.

Alginate SMT (anionic sodium alginate, CHT, Turkey) has been used as a thickener and Verolan TTY (ionic alkyl phosphonate mixture, Rudolf Duraner, Germany) has been used as an ion immobilizer for the preparation of the amorphous silica added printing paste.

\section{EXPERIMENTAL MODELING METHOD}

Printing recipes within the study are as follows.

$\begin{array}{ll}\text { Pumice or Colemanite } & 25 / 50 / 100 \mathrm{~g} \\ \text { Distilled Water } & \text { X g } \\ \text { Tubivis VP 681 } & 17 \mathrm{~g} \\ \text { Tubiprint Fixerer RE } & 10 \mathrm{~g} \\ & 1000 \mathrm{~g}\end{array}$

$\begin{array}{ll}\text { Amorphous Silica } & 25 / 50 / 100 \mathrm{~g} \\ \text { Distilled Water } & \mathrm{Xg} \\ \text { Alginat SMT } & 40 \mathrm{~g} \\ \text { Verolan TTY } & 1 \mathrm{~g} \\ & 1000 \mathrm{~g}\end{array}$

Printing of cotton fabrics have been carried out in accordance with the prescribed printing recipe and conditions $[4,15]$. The printing process has been carried out in two rounds by using the prepared wooden printing templates. After printing stage, the fabric samples have been dried at $100^{\circ} \mathrm{C}$ for 3 minutes. The conditioning of the finished printing samples has been applied under standard atmospheric conditions $\left(65 \pm 2 \%\right.$ relative humidity and $\left.20 \pm 2^{\circ} \mathrm{C}\right)$ for 24 hours.

After printing, wet weights were measured to ensure equal transfer of cotton and polyester fabric samples, and fabrics containing about the same value of printing paste have been taken as basis for the tests. The weight values of the cotton fabric samples after the approximate printing paste application are $440 \mathrm{~g} / \mathrm{m}^{2}$. The zeta potentials of all solid particulate materials (pumice, amorphous silica and colemanite) used in the printing process have been examined. When the zeta potential - $\mathrm{pH}$ graphs of pumice, colemanite and amorphous silica are examined, it is seen that all the materials in the basic region show common properties and have negative charges [4, 16, 17-18]. In this case, the sol gel solution has been prepared as basic catalyzed.

Sol gel recipe within the study is as follow:

$\begin{array}{lc}\text { Chemicals } & \text { Amount } \\ \text { TEOS } & 11 \mathrm{ml} \\ \text { Ethanol } & 50 \mathrm{ml} \\ \text { Distilled Water } & 35 \mathrm{ml} \\ \text { NaOH } & *\end{array}$

( ${ }^{*}$ During the preparation of the sol gel solution, $0.1 \mathrm{~N}$ $\mathrm{NaOH}$ was added at a $\mathrm{pH}$ value of 9-10.)

Sol gel solution was stirred by magnetic stirrer at $25{ }^{\circ} \mathrm{C}$ for 30 mins and the process has been proceeded until the clear solution is obtained. The $\mathrm{pH}$ value of the obtained solution has been measured as 9.7 .

After obtain of the sol gel solution, the cotton fabric samples have been coated with horizontal fulard at a rate $3.5 \mathrm{~m} / \mathrm{min}$ under 2 bar pressure in 2 passages. Fixing of the coated fabrics has been carried out at $100^{\circ} \mathrm{C}$ for 3 minutes and the fabric samples were conditioned under standard atmospheric conditions for 24 hours.

TESCAN MAIA3 XMU brand high-resolution scanning electron microscope has been used to display the surface morphology of the cotton fabric samples and to perform\% elemental EDS point analysis. For the qualitative analysis of the samples, Shimadzu brand IRAffinity-1 model F-TIR device has been.

Fabric tensile strength and tear strength measurements have been carried out with the Lloyd LR5K Plus strength tester in accordance with TS EN ISO 13934-1 and TS EN ISO 13937-2. UV transmission properties of cotton fabrics have been measured by UV-VIS-NIR Spectrophotometer UV-3600 Plus according to AS/NZS 4399-1196 standard. Air permeability of fabrics has been measured by Textest FX 3300 according to ASTM D 737. The flame retardancy tests which have been carried out using the $45^{\circ}$ flammability tester, Bellmore, model TC-45 has been evaluated according to ASTM 1230-450. The measurement of the wear resistance of the fabric samples has been carried out in accordance with TS EN ISO 12945-2 using Nu-Martindale M 406 pilling and abrasion tester. The contact angle measurement of the samples has been made with the OCA 15 PLUS tester and the water permeability test has been carried out in accordance with the AATCC 42-2007 standard to measure water permeability values. Statistical evaluation of the test results applied to fabric samples has been evaluated via SPSS 18.0 Statistical Package Program.

\section{RESULTS AND DISCUSSION}

\section{Surface morphology analyses}

SEM photos of cotton fabric samples are given in figure 1.

When SEM photos of fabrics are examined, it was observed that the structures are formed after printing process and sol gel process on fabric surfaces.

The results of EDS analyses of cotton fabrics are given in figure 2 .

When the EDS analyses results were examined, it was determined that the chemical components ( $\mathrm{Si}, \mathrm{K}$, $\mathrm{Al}, \mathrm{Fe}, \mathrm{Ca}, \mathrm{Na}, \mathrm{O}, \mathrm{Ti}, \mathrm{B}, \mathrm{Ca}$ ) of all the additive materials (pumice, amorphous silica and colemanite) were present on the fabric surfaces.

The F-TIR spectras of pumice and cotton fabric coated with pumice are given figure 3 .

Figure 3 indicates the F-TIR ATR absorbance spectre of pumice and cotton fabric treated with pumice. The band between 3200 and $3800 \mathrm{~cm}^{-1}$ are due to $\mathrm{O}-\mathrm{H}$ stretching, between 3200 and $2800 \mathrm{~cm}^{-1}$ are due to $\mathrm{Al}-\mathrm{OH}$ stretching $[4,19,20,21,22]$. While the peak is found at $1716 \mathrm{~cm}^{-1}$ and the band between 1640 


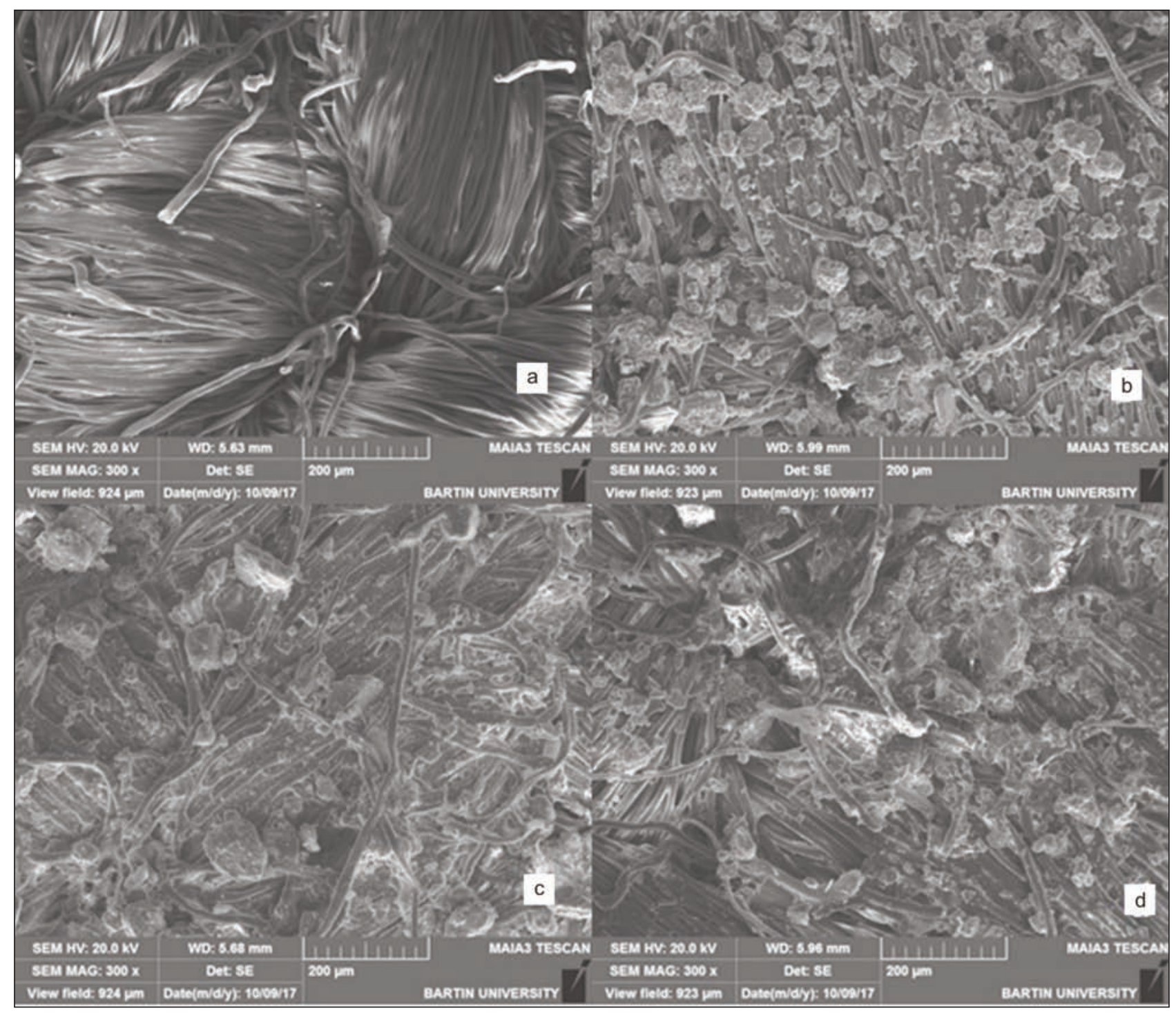

Fig. 1. SEM photos of cotton fabric (a), cotton fabric coated with pumice (b), cotton fabric coated with amorphous silica (c) and cotton fabric coated with colemanite (d)

and $1690 \mathrm{~cm}^{-1}$ are due to $\mathrm{C}-\mathrm{O}-\mathrm{C}$ stretching $[4,20$, 23]. The band between 1000 and $1110 \mathrm{~cm}^{-1}$ are due to $\mathrm{Si}=\mathrm{O}$ and $\mathrm{Si}-\mathrm{O}$ stretching $[4,15,19,21,24]$. Additionally, these peaks are between 900 and 1000 $\mathrm{cm}^{-1}$ are due $\mathrm{Si}-\mathrm{OH}$ stretching and the peak at 742 $\mathrm{cm}^{-1}$ is due to $\mathrm{Mg}-\mathrm{Fe}-\mathrm{OH}[4,20,25]$.

The F-TIR spectras of amorphous silica and cotton fabric coated with amorphous silica are given figure 4.

Figure 4 indicates the F-TIR ATR absorbance spectre of amorphous silica and cotton fabric treated with amorphous silica. The band between 3200 and 3800 $\mathrm{cm}^{-1}$ are due to $\mathrm{O}-\mathrm{H}$ stretching and between 2200 and $2400 \mathrm{~cm}^{-1}$ are due to $\mathrm{C}-\mathrm{H}$ stretching $[4,19,21]$. While the peaks on the band between 1400 to 1690 $\mathrm{cm}^{-1}$ are due to $\mathrm{COO}^{-}$and $\mathrm{C}=\mathrm{O}$ stretching $[4,26$, 27]. The band from 1000 to $1110 \mathrm{~cm}^{-1}$ is due to $\mathrm{Si}=0$ and $\mathrm{Si}-\mathrm{O}$ stretching that caused a peak at $1038 \mathrm{~cm}^{-1}$. This is as a result of the presence of $\mathrm{SiO}_{2}$ in the amorphous silica structure $[4,15,19,21,24]$. Additionally, the peak at $786 \mathrm{~cm}^{-1}$ is due to amorphous silica and TEOS originated $\mathrm{SiO}_{2}$ compound [15, 21].
The F-TIR spectras of colemanite and cotton fabric coated with colemanite are given figure 5 .

In figure 5, F-TIR analyses of colemanite and cotton fabric treated with colemanite are illustrated. As in all figures, the band between 3200 and $3800 \mathrm{~cm}^{-1}$ is caused by $\mathrm{O}-\mathrm{H}$ stretching and between 2200 and $2400 \mathrm{~cm}^{-1}$ are due to $\mathrm{C}-\mathrm{H}$ stretching $[4,19,21]$. The band between 1640 and $1690 \mathrm{~cm}^{-1}$ resulted from $\mathrm{C}=\mathrm{O}$ stretching. The peak at $1654 \mathrm{~cm}^{-1}$ is due to $\mathrm{H}-\mathrm{O}-\mathrm{H}$ stretching and the peaks at 1558 and 1450 $\mathrm{cm}^{-1}$ are attributed to $B_{3}-O$ stretching $[4,15,28]$. The peak at $1311 \mathrm{~cm}^{-1}$ and $1122 \mathrm{~cm}^{-1}$ are because of $\mathrm{B}-\mathrm{OH}$ and $\mathrm{B}_{4}-\mathrm{O}$ stretchings [29]. The band at 1000 to $1110 \mathrm{~cm}^{-1}$ are due to $\mathrm{Si}=\mathrm{O}$ and $\mathrm{Si}-\mathrm{O}$ stretching which caused peaks at 802 and $874 \mathrm{~cm}^{-1}$. This could be attributed to the existence of $\mathrm{SiO}_{2}$ in the amorphous silica structure and TEOS [4, 15, 21].

Tensile strength and tearing strength values of cotton fabrics

The tensile strength and elongation values of untreated and treated fabrics are given in table 2 . 

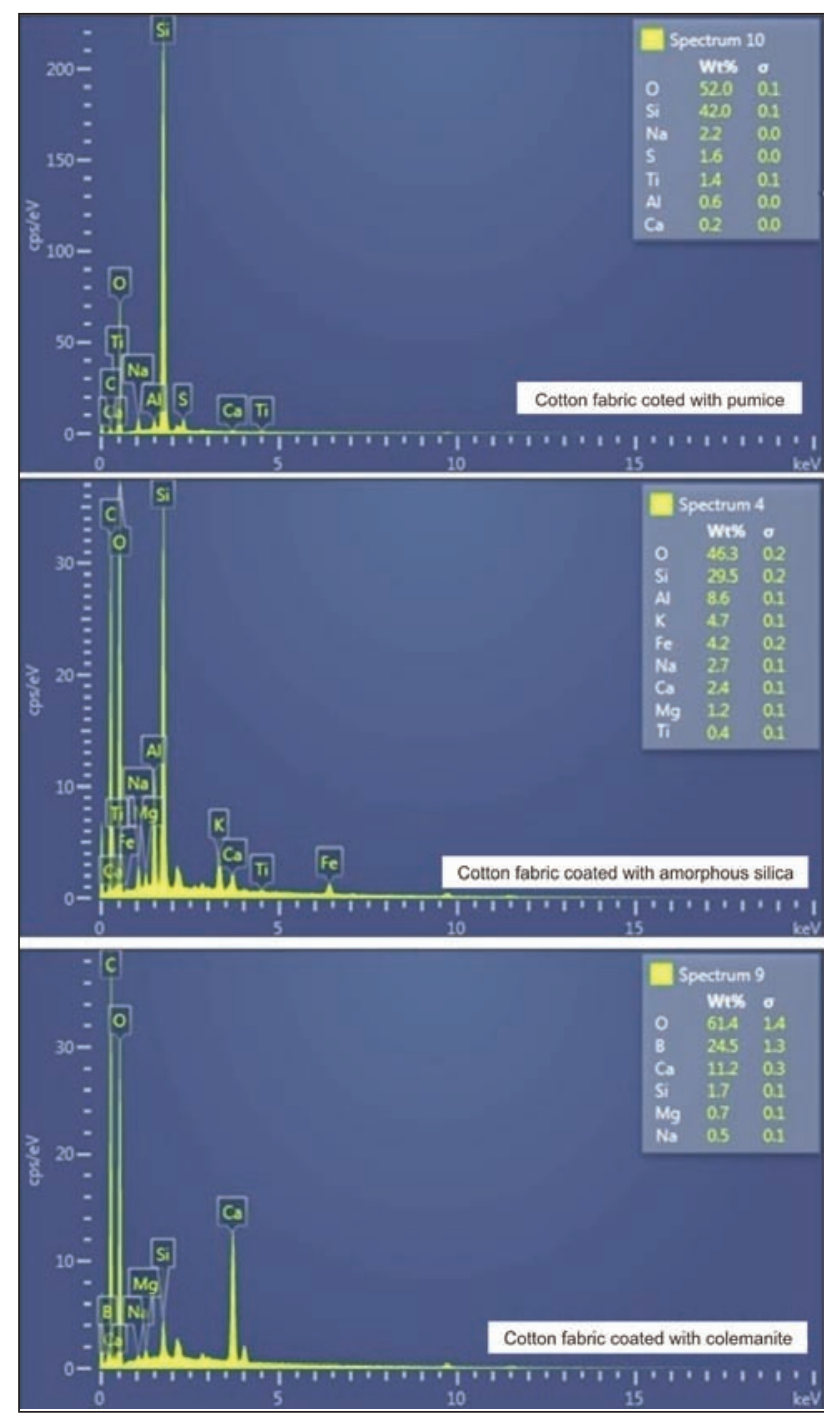

Fig. 2. The results of EDS analyses of cotton fabrics

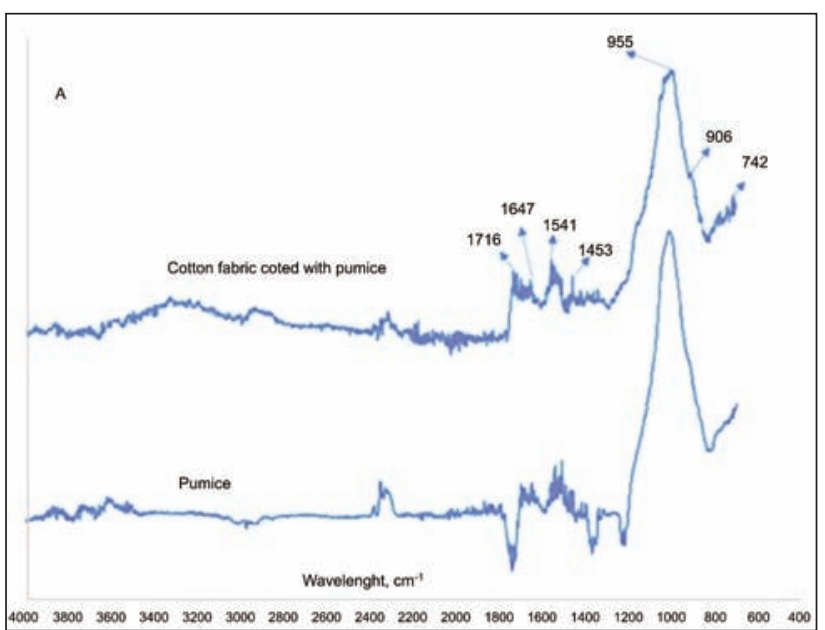

Fig. 3. The F-TIR spectras of pumice and cotton fabric coated with pumice

As seen in the values from table 2 the tensile strength of cotton fabric samples increased significantly after the printing and sol gel processes. When the table is examined in details, it is seen that the highest strength values are attained after $100 \mathrm{~g} / \mathrm{kg}$ colemanite added printing and sol gel processing. When 100

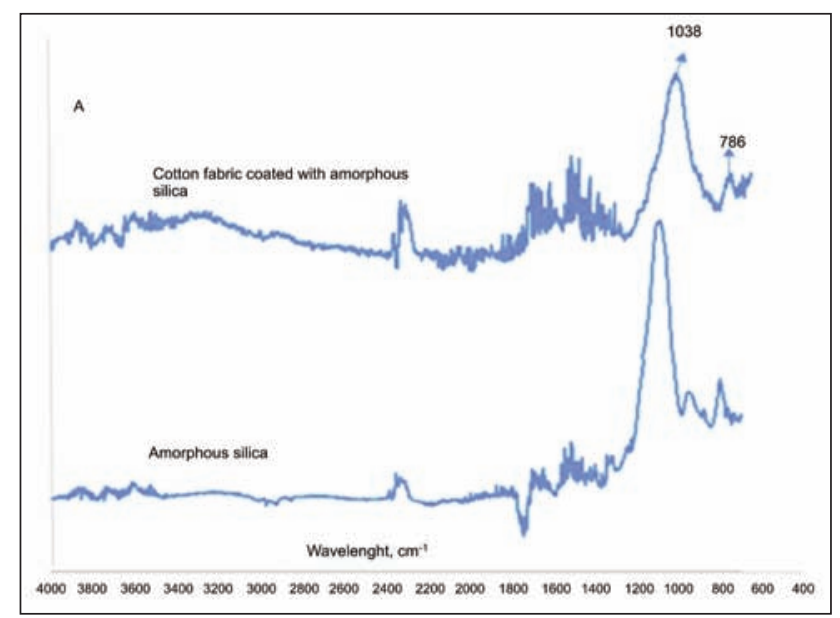

Fig. 4. The F-TIR spectras of amorphous silica and cotton fabric coated with amorphous silica

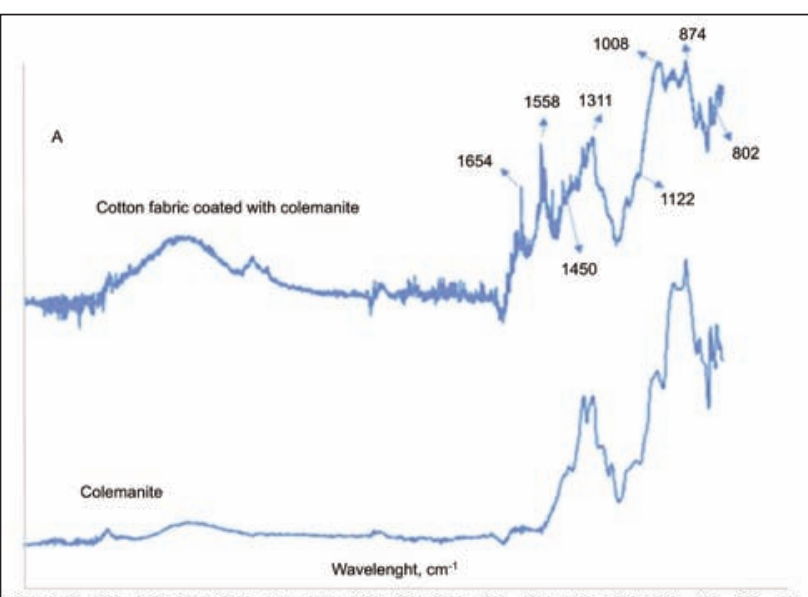

Fig. 5. The F-TIR spectras of colemanite and cotton fabric coated with colemanite

$\mathrm{g} / \mathrm{kg}$ colemanite was addedinto the printing paste and sol gel process was performed, the tensile strength increased by $41 \%$ in the warp direction and by $34 \%$ in the weft direction. After $100 \mathrm{~g} / \mathrm{kg}$ of amorphous silica was added to the printing paste and sol gel process, the tensile strength increased by $32 \%$ in the warp direction and by $11 \%$ in the weft direction. After $100 \mathrm{~g} / \mathrm{kg}$ pumice added process; the warp direction tensile strength value was increased by $35 \%$ and the weft direction tensile strength was increased by $16 \%$.It is also seen that the values of tensile strength are increased in parallel with the addition ratio for all materials.

When an untreated cotton fabric is subjected to a force parallel to the fiber axis, the macromolecules in the fiber structure and the crystallites are formed resulting to a reaction against cohesive forces and the force tends to break when the force reaches a value above this effect. Rupture occurs in the oxygen bridge connecting the macromolecules. After the printing paste and pumice, amorphous silica and colemanite structures on the fabric samples, the resistance of the fabric samples to the breaking forces increased resulting to the increment of the tensile strength value $[4,15]$. 


\begin{tabular}{|c|c|c|c|c|c|}
\hline \multirow{2}{*}{$\begin{array}{c}\text { Amount } \\
\mathbf{( g / k g )}\end{array}$} & \multicolumn{2}{|c|}{ Tensile strenght (N) } & \multicolumn{2}{c|}{ Elongation (\%) } \\
\cline { 2 - 5 } & $\mathbf{W a r p}$ & $\mathbf{W e f t}$ & Warp & Weft \\
\hline \multirow{3}{*}{$\begin{array}{c}\text { Cotton fabric treated } \\
\text { with pumice }\end{array}$} & 100 & 1526,50 & 17,011 & 877,07 & 19,573 \\
\cline { 2 - 6 } & 50 & 1343,32 & 16,689 & 867,77 & 19,099 \\
\cline { 2 - 6 } & 25 & 1315,16 & 16,032 & 857,73 & 18,530 \\
\hline \multirow{2}{*}{$\begin{array}{c}\text { Cotton fabric treated } \\
\text { with amorphous silica }\end{array}$} & 100 & 1484,67 & 16,335 & 840,53 & 18,646 \\
\cline { 2 - 6 } & 50 & 1470,14 & 15,889 & 829,27 & 17,449 \\
\hline \multirow{2}{*}{$\begin{array}{c}\text { Cotton fabric treated } \\
\text { with colemanite }\end{array}$} & 25 & 1414,13 & 14,941 & 816,25 & 16,711 \\
\cline { 2 - 6 } & 100 & 1584,49 & 17,317 & 1008,38 & 19,0842 \\
\cline { 2 - 6 } & 50 & 1439,81 & 17,045 & 911,80 & 18,607 \\
\hline Cotton fabric & 25 & 1338,14 & 16,808 & 889,57 & 16,667 \\
\hline
\end{tabular}

The elongation values of the cotton fabric samples after the pumice, amorphous silica and colemanite added printing and sol gel coating processes have lower values than the untreated fabric samples. The reason for this result is that a new and rigid structure is formed on the surface of the fabric with natural based material, thickener and sol gel layer after printing and sol gel coating process $[4,15]$.

The values of the tensile strength and elongation obtained after the processes with all materials were evaluated with One Way Anova test. As a result of the analysis made, the sigma value for both warp and weft direction was found to be 0,000 . After the homogeneity of the variance, the sigma value is calculated as 0,000 . This result indicates a heterogeneous distribution of variances. It is determined that there is a significant statistical difference between all the processes after the analysis using the technique Tamhane's T2 post hoc.

The tearing strength values of untreated and treated fabrics are given in table 3 .

Table 3

\begin{tabular}{|c|c|c|c|}
\hline \multirow{2}{*}{$\begin{array}{c}\text { Amount } \\
\text { (g/kg) }\end{array}$} & \multicolumn{2}{|c|}{ Tearing strenght (N) } \\
\cline { 2 - 4 } & Warp & Weft \\
\hline \multirow{2}{*}{$\begin{array}{c}\text { Cotton fabric } \\
\text { treated } \\
\text { with pumice }\end{array}$} & 100 & 44,93 & 34,52 \\
\cline { 2 - 4 } & 50 & 43,02 & 33,83 \\
\cline { 2 - 4 } & 25 & 40,33 & 31,08 \\
\hline \multirow{2}{*}{$\begin{array}{c}\text { Cotton fabric } \\
\text { treated with } \\
\text { amorphous silica }\end{array}$} & 100 & 44,95 & 34,05 \\
\cline { 2 - 4 } & 50 & 43,19 & 33,36 \\
\hline \multirow{2}{*}{$\begin{array}{c}\text { Cotton fabric } \\
\text { treated with } \\
\text { colemanite }\end{array}$} & 25 & 38,10 & 31,28 \\
\cline { 2 - 4 } & 100 & 47,14 & 37,16 \\
\cline { 2 - 4 } & 25 & 46,09 & 36,08 \\
\hline Cotton fabric & - & 37,27 & 34,22 \\
\hline
\end{tabular}

When the table is examined, the highest values in tearing strength are attained after $100 \mathrm{~g} / \mathrm{kg}$ of colemanite added processes as well as in tensile strength values. After $100 \mathrm{~g} / \mathrm{kg}$ colemanite addition process, an increase of $27 \%$ in the warp direction and $23 \%$ in the weft direction were obtained.

The results show that the highest tensile and tearing strength values for all samples are obtained after colemanite added processes. The reason for this result is the $\mathrm{B}$ based new bonds $\left(\mathrm{B}-\mathrm{OH}, \mathrm{B}_{4}-\mathrm{O}\right)$ formed in the colemanite structure. These bonds are the result of $\mathrm{B}_{2} \mathrm{O}_{3}$ compound, which is $40 \%$ in the structure of colemanite.

\section{UV resistance values of cotton fabrics}

Textile materials have different reflectivity and absorption rates of sun UV radiation. Fibers with low UV absorption properties, such as cotton fabrics are considered to be more risky than fibers containing polymers with high absorption properties [30, 31].

In this study, transmittance values of the fabrics were measured in UV A (315-400 nm) and UV B (290-315 $\mathrm{nm}$ ) regions with $5 \mathrm{~nm}$ wavelength intervals according to AS/NZS 4399-1996 standard. The results obtained after measurement are given in figure 6 .

The results obtained from UVA and UVB measurements of cotton fabrics are given in table 4 .

When the obtained data in table 1 are analyzed, it is seen that the cotton fabric samples have the lowest $\%$ transmittance values in the UVA and UV B regions after the amorphous silica added printing and sol gel process. The highest UV protection values for cotton

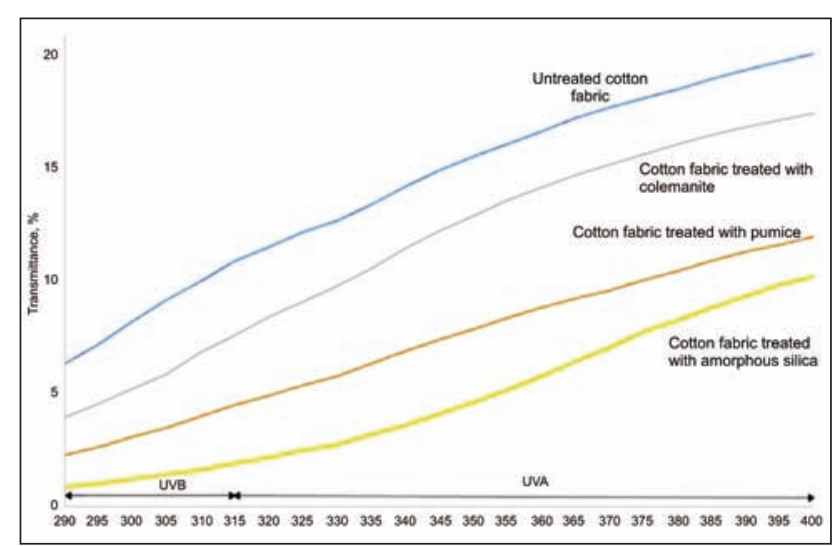

Fig. 6. \% Transmittance values of cotton fabrics 


\begin{tabular}{|l|c|c|}
\hline & \% UV A & \% UV B \\
\hline Cotton fabric & 15,93 & 8,61 \\
\hline $\begin{array}{l}\text { Cotton fabric treated with } \\
\text { pumice }\end{array}$ & 8,38 & 3,33 \\
\hline $\begin{array}{l}\text { Cotton fabric treated with } \\
\text { colemanite }\end{array}$ & 13,24 & 5,66 \\
\hline $\begin{array}{l}\text { Cotton fabric treated with } \\
\text { amorphous silica }\end{array}$ & 5,73 & 1,35 \\
\hline
\end{tabular}

fabric samples after the process added amorphous silica are due to the refractive optical material property of the amorphous silica. The reason is that the hydroxides $\left(\mathrm{OH}^{-}\right)$present in amorphous silica can absorb some wave lengths well and absorb $\mathrm{Si}-\mathrm{O}$ vibration at high intervals $[4,32]$.

\section{Air permeability values of cotton fabrics}

The air permeability values of the cotton fabric samples are given in table 5 .

Table 5

\begin{tabular}{|c|c|c|}
\hline \multirow{2}{*}{$\begin{array}{c}\text { Cotton fabric treated } \\
\text { with pumice }\end{array}$} & $\begin{array}{c}\text { Amount } \\
\text { (g/kg) }\end{array}$ & $\begin{array}{c}\text { Air } \\
\text { permeability } \\
\text { (L/m²/s) }\end{array}$ \\
\cline { 2 - 3 } & 100 & 52,66 \\
\hline \multirow{2}{*}{$\begin{array}{c}\text { Cotton fabric treated } \\
\text { with amorphous silica }\end{array}$} & 50 & 55,01 \\
\cline { 2 - 3 } & 25 & 58,41 \\
\hline \multirow{2}{*}{$\begin{array}{c}\text { Cotton fabric treated } \\
\text { with colemanite }\end{array}$} & 100 & 11,71 \\
\cline { 2 - 3 } & 50 & 12,86 \\
\cline { 2 - 3 } & 25 & 13,06 \\
\hline Cotton fabric & 50 & 65,87 \\
\hline
\end{tabular}

According to table 5 air permeability values of all cotton fabrics is decreased as a results of processes. The lowest air permeability values were attained after amorphous silica added printing and sol gel process. This can be explained by the density of $\mathrm{SiO}_{2}$ bonds formed and the natural alginate thickener used. In contrast to the pumice and colemanite addition processes using synthetic thickeners, a denser layer is obtained on the surface of the amorphous silicaadded fabric after the use of a natural thickener with a high solids content.

One-way ANOVA analysis of the obtained air permeability values revealed that the resulting sigma value was 0,000 and that all the procedures had a statistically significant difference. This proves that all processes with additive materials are effective on the cotton fabric.

\section{Flame retardancy values of cotton fabrics}

The flame retardancy values of cotton fabric samples after pumice, amorphous silica and colemaniteadded printing and sol gel processing are given in table 6 .

\begin{tabular}{|c|c|c|c|}
\hline & $\begin{array}{c}\text { Amount } \\
\mathbf{( g / k g})\end{array}$ & $\begin{array}{c}\text { Igniton } \\
\text { time (s) }\end{array}$ & $\begin{array}{c}\text { Yarn } \\
\text { breakage } \\
\text { time (s) }\end{array}$ \\
\hline \multirow{2}{*}{$\begin{array}{c}\text { Cotton fabric } \\
\text { treated with } \\
\text { pumice }\end{array}$} & 100 & 22,62 & 57,82 \\
\cline { 2 - 4 } & 50 & 21,82 & 56,34 \\
\cline { 2 - 4 } & 25 & 18,22 & 53,62 \\
\hline \multirow{2}{*}{$\begin{array}{c}\text { Cotton fabric } \\
\text { treated with } \\
\text { amorphous silica }\end{array}$} & 100 & not burnt & not burnt \\
\cline { 2 - 4 } & 50 & not burnt & not burnt \\
\hline \multirow{2}{*}{$\begin{array}{c}\text { Cotton fabric } \\
\text { treated with } \\
\text { colemanite }\end{array}$} & 100 & not burnt & not burnt \\
\cline { 2 - 4 } & 50 & 26,36 & 76,4 \\
\cline { 2 - 4 } & 25 & 23,72 & 75,32 \\
\hline Cotton fabric & - & 15,64 & 73,6 \\
\hline
\end{tabular}

When the test results are examined, it is seen that the samples of cotton fabrics have nonflammable properties after amorphous silica-added processes. This is explained by the non-flammability properties of the sodium alginate based thickener used in the amorphous silica printing recipe. In the same test, after the colemanite addition process, the flammability properties of the fabric samples increased and the burning times increased by $220 \%$ compared to the untreated fabric sample. Due to the $\mathrm{B}_{2} \mathrm{O}_{3}$ and $\mathrm{MgO}$ compounds found in the colemanite structure, it exhibits a high non-flammable characteristic $[4,15]$.

\section{Wear resistance values of cotton fabrics}

$\%$ Weight changes of fabric samples after 5,000 , 10,000 and 20,000 cycles were measured for the measurement of wear resistance of cotton fabric samples. The obtained results are given in table 7 . When the table is examined, it is seen that cotton fabric samples treated with amorphous silica have the lowest $\%$ weight loss value after 20,000 cycles. The highest wear resistance was attained after amorphous silica added printing and sol gel processing because of the formation of a denser and more valid structure on the surface of the natural based thickener welded fabric. In addition, when the table is examined, it shows that the wear resistance of all fabric samples that are processed in compored to the nontreated fabric sample is increased.

\section{The contact angles and water permeability values of cotton fabrics}

The contact angle measurement results of cotton fabric samples after pumice, amorphous silica and colemanite addition printing and sol gel coating process are given in the table 8 .

Water permeability measurement results of cotton fabric samples after pumice, amorphous silica and colemanite addition printing and left gel coating process are given in table 9 .

When the obtained contact angle and water permeability results are examined, it is seen that the contact angle and water permeability values are improved 


\begin{tabular}{|c|c|c|c|c|c|c|c|c|}
\hline & $\begin{array}{c}\text { Amount } \\
(\mathrm{g} / \mathrm{kg})\end{array}$ & $\begin{array}{l}\text { Weight } \\
\text { (g) }\end{array}$ & $\begin{array}{l}\text { Weight } \\
\text { change } \\
\text { after } 5000 \\
\text { cycles }(g)\end{array}$ & $\begin{array}{l}\text { Weight } \\
\text { loss (\%) }\end{array}$ & $\begin{array}{c}\text { Weight } \\
\text { change } \\
\text { after } 10000 \\
\text { cycles }(\mathrm{g})\end{array}$ & $\begin{array}{l}\text { Weight } \\
\text { loss (\%) }\end{array}$ & $\begin{array}{c}\text { Weight } \\
\text { change } \\
\text { after } 20000 \\
\text { cycles }(\mathrm{g})\end{array}$ & $\begin{array}{l}\text { Weight } \\
\text { loss (\%) }\end{array}$ \\
\hline Cotton fabric & - & 0,485 & 0,479 & 1,318 & 0,473 & 2,430 & 0,469 & 3,418 \\
\hline \multirow{3}{*}{$\begin{array}{l}\text { Cotton fabric } \\
\text { treated with } \\
\text { pumice }\end{array}$} & 100 & 0,608 & 0,597 & 1,742 & 0,593 & 2,465 & 0,591 & 2,827 \\
\hline & 50 & 0,594 & 0,585 & 1,647 & 0,582 & 2,118 & 0,580 & 2,353 \\
\hline & 25 & 0,588 & 0,578 & 1,698 & 0,576 & 2,072 & 0,575 & 2,310 \\
\hline \multirow{3}{*}{$\begin{array}{c}\text { Cotton fabric } \\
\text { treated with } \\
\text { amorphous silica }\end{array}$} & 100 & 0,604 & 0,600 & 0,662 & 0,599 & 0,827 & 0,598 & 0,993 \\
\hline & 50 & 0,595 & 0,592 & 0,504 & 0,591 & 0,672 & 0,590 & 0,846 \\
\hline & 25 & 0,591 & 0,589 & 0,338 & 0,587 & 0,676 & 0,586 & 0,840 \\
\hline \multirow{3}{*}{$\begin{array}{l}\text { Cotton fabric } \\
\text { treated with } \\
\text { colemanite }\end{array}$} & 100 & 0,591 & 0,573 & 3,041 & 0,570 & 3,682 & 0,568 & 4,021 \\
\hline & 50 & 0,561 & 0,547 & 2,423 & 0,545 & 2,779 & 0,543 & 3,100 \\
\hline & 25 & 0,554 & 0,542 & 2,306 & 0,540 & 2,631 & 0,537 & 3,064 \\
\hline
\end{tabular}

Table 8 Morphological and elemental analyses have been

\begin{tabular}{|l|c|}
\hline Cotton fabric & $\begin{array}{c}\text { Contact } \\
\text { angle }\end{array}$ \\
\hline Cotton fabric treated with pumice & $14,5^{\circ}$ \\
\hline Cotton fabric treated with amorphous silica & $68,5^{\circ}$ \\
\hline Cotton fabric treated with colemanite & $25,5^{\circ}$ \\
\hline
\end{tabular}
proven to be successful in transferring the chemical compounds of natural basis materials used in the new process to cotton fabric samples.

In this study, several finishing processes (tensile strength, tear strength, air permeability, flame retardant, UV protection) were applied simultaneously using completely natural based materials. In addition,

Table 9

\begin{tabular}{|l|c|c|c|}
\hline \multicolumn{1}{|c|}{ Numune } & $\begin{array}{c}\text { Weight of blotting } \\
\text { paper } \mathbf{( g )}\end{array}$ & $\begin{array}{c}\text { Weight of blotting } \\
\text { paper after test (g) }\end{array}$ & Weight of water (g) \\
\hline Cotton fabric & 13,29 & 44,15 & 30,86 \\
\hline Cotton fabric treated with pumice & 13,05 & 36,27 & 23,22 \\
\hline Cotton fabric treated with colemanite & 12,98 & 30,12 & 17,14 \\
\hline Cotton fabric treated with amorphous silica & 12,96 & 40,76 & 27,8 \\
\hline
\end{tabular}

according to the untreated fabric sample after all processes. However, when the obtained values are interpreted according to the standards, it is seen that the cotton fabric samples do not become water repellent.

\section{CONCLUSIONS}

In the study, the changes in the physical properties of cotton fabric printed with pumice, amorphous silica and colemanite and fixed with sol gel method were investigated. As a result of the obtained data, it is concluded that all the processing steps are effective on the tensile and tear strength, air permeability, flame retardancy, UV protection, wear resistance properties of cotton fabrics. an example in textile has been created for the applicability of the sol gel process, which is developing and widespread in many fields.

Because it uses resources effectively, it is more ecofriendly and the fact that it has lower energy cost due to lower fixation temperature; sol gel method in textile has been closely examined. It has also been proved in this study that it will be a prominent source for future studies of researches in this field.

\section{ACKNOWLEDGEMENTS}

The authors thank Süleyman Demirel University Scientific Research Coordination Unit, Isparta, Turkey for contributions to the project and financial support.

\section{BIBLIOGRAPHY}

[1] Brinker, C., Scherer, G. Sol-Gel Science. The physics and chemistry of sol-gel processing, In: Academic Press, New York, 2013, 912 p.

[2] Toygun, Ş., Köneçoğlu, G., Kalpaklı, Y. General principles of sol-gel. In: Sigma, 2013, vol. 31, pp. $456-476$. 
[3] Livage, J., Beteille, F., Roux, C. Sol-Gel synthesis of oxide materials. In: Acta Materialia, 1998, vol. 46, issue 3 , pp. 743-750.

[4] Akçalı, K. Doğal Esaslı Malzemeler Kullanılarak Sol Jel Kaplama Metodu İle Pamuklu Ve Polyester Kumaşların Fiziksel Özelliklerinin Araştırılması, Süleyman Demirel Üniversitesi, In: Fen Bilimleri Enstitüsü, Doktora Tezi, Isparta, 2017, $175 \mathrm{p}$.

[5] Gündüz, L., Sarışık, A., Tozaçan, B., Davraz, M., Uğur, İ., Çankıran, O. Pomza Teknolojisi Cilt I, Süleyman Demirel Üniversitesi, In: Isparta, 1998, 285 p.

[6] Amato, G., Campione, G., Cavaleri, L., Minafo, N., Miraglia, N. The use of pumice light weight concrete for masonry applications. In: Materials and Structure, 2012, vol. 45, issue 5, pp. 679-693.

[7] Karabay, D. Değişik Oranlarda Pomza, Talk ve Serpantin Illavelerinin Fayans Masse Üzerine Etkileri, Dumlupınar Üniversitesi, In: Fen Bilimleri Enstitüsü, Yüksek Lisans Tezi, Kütahya, 2006, 73 p.

[8] Aksoy, E. Isparta Gelincik Pomza Yataklarının Jeolojisi, Fizikselve Mekanik Özelliklerinin Araştırılması. Selçuk Üniversitesi, In: Fen Bilimleri Enstitüsü, Yüksek Lisans Tezi, Konya, 2010, 86 p.

[9] Kabaş, N.G. Modifiye Edilmiş Pomzaile Ağır Metal Uzaklaştırılması. Süleyman Demirel Üniversitesi, In: Fen Bilimleri Enstitüsü, Yüksek Lisans Tezi, Isparta, 2007, 78 p.

[10] Davraz, M. Isparta Keçiborlu Yöresi Doğal Amorf Silika Oluşumlarının Gelenekselve Hafif Beton Endüstrilerinde Kullanılabilirliğinin Araştırılması. Süleyman Demirel Üniversitesi, In: Fen Bilimleri Enstitüsü, Doktora Tezi, Isparta, 2004, 244 p.

[11] Dereli, B. Borve Amorf Silikanın Betonitin Mühendislik Özelliklerine Etkisi. Süleyman Demirel Üniversitesi, In: Fen Bilimleri Enstitüsü, Yüksek Lisans Tezi, Isparta, 2013, 62 p.

[12] Beall, H.G. Industrial Aplication of Silica. Silica Physical Behaviour, In: Geochemistry and Materials Applications, 1994, vol. 29, pp. 469-504.

[13] Shackelford, J., Doremus, R.H. (Eds.), Ceramic and glass materials structure, properties and processing, In: Springer, New York, 2008, 202 p.

[14] Korçak, Ö. Kolemanit Atıklarının Çimento Üretiminde Kullanılmasıve Çimentonun Performans Özelliklerinin Geliştirilmesi, Gazi Üniversitesi, In: Fen Bilimleri Enstitüsü, Doktora Tezi, Ankara, 2014, 139 p.

[15] Oktav Bulut, M., Çimen, Ö., Akbulut, Y., Akçalı, K., Dereli, B. Application of amorphous silica, colemanite and pumice on cotton fabric by screen printing method, In: Industria Textila, 2015, vol. 66, issue 5, pp. 289-296.

[16] Asgari, G., Roshani, B., Ghanizadeh, G. The investigation of kinetic and isotherm of fluoride adsorption onto functionalize pumice stone, In: Journal of Hazardous Materials, 2012, vol. 217, pp. 123-132.

[17] Zhao, X., Shi, Y., Wang, T., Cai, Y., Jiang, G. Preparation of silica-magnetite nanoparticle mixed hemimicelle sorbents for extraction of several typical phenolic compounds from environmental water samples, In: Journal of Chromatography A, 2008, vol. 1188, pp. 140-147.

[18] Özkan, S. G., Güngören, C. Enhancement of colemanite flotation by ultrasonic pre-treatment, In: Physicochemical Problems of Mineral Processing, 2012, vol. 48, issue 2, pp. 455-462.

[19] Cireli, A., Onar, N., Ebeoğlugil, M. F., Kayatekin, I., Kutlu, B., Culha, O., Çelik, E. Development of flame retardancy properties of new halogen-free phosphorous doped $\mathrm{SiO}_{2}$ thin films on fabrics, In: Journal of Applied Polymer Science, 2007, vol. 105, pp. 3747-3756.

[20] Tunç, S., Duman, O. Effect of electrolytes on the electro kinetic properties of pumice suspensions, In: Journal of Dispersion Science and Technology, 2009, vol. 30, pp. 548-555.

[21] Onar, N., Mete, G., Akşit, A., Kutlu, B., Çelik, E. Water and oil repellency properties of cotton fabric treated with silane, Zr, Ti based nanosols, In: International Journal of Textile Science, 2015, vol. 4, issue 4, pp. 84-96.

[22] Khorzughy, S.H., Eslamkish, T., Ardejani, F.D., Heydartaemeh, M.R. Cadmium removal from aqueous solutions by pumice and nano-pumice, In: Korean Journal of Chemical Engineers, 2015, vol. 32, issue 1, pp. 88-96.

[23] Mourhly, A., Khachani, M., El Hamadi, A., Kacimi, M., Halim, M., Arsalane, S. The synthesis and characterization of low-cost mesoporous silica $\mathrm{SiO}_{2}$ from local pumice rock, In: Nanomaterials and Nanotechnology, 2015, vol. 5, issue 35, pp. 1-7.

[24] Nariyal, R.K., Kothari, P., Bisht, B. FTIR measurements of $\mathrm{SiO}_{2}$ glass prepared by sol-gel technique, In: Chemical Science Transactions, 2014, vol. 3, issue 3, pp. 1064-1066.

[25] Tyagi, B., Chudasama, C.D., Jasra, R.V. Determination of structural modification in acid activated montmorillonite clay by FT-IR spectroscopy, In: Spectrochimica Acta Part A, 2006, vol. 64, pp. 273-278.

[26] Madejova, J. FTIR techniques in clay mineral studies, In: Vibrational Spectroscopy, 2003, vol. 31, pp. 1-10.

[27] Kitadai, N., Yokoyama, T., Nakashima, S. ATR-IR spectroscopic study of L-lysine adsorption on amorphous silica, In: Journal of Colloid and Interface Science, 2009, vol. 329, pp. 31-37.

[28] Kızılca, M., Copur, M. Thermal dehydration of colemanite: Kinetics and mechanism determined using the master plots method, In: Canadian Metallurgical Quarterly, 2017, vol. 56, issue 3, pp. 259-271.

[29] Budak, A., Gönen, M. Extraction of boric acid from colemanite mineral by supercritical carbon dioxide, In: The Journal of Supercritical Fluids, 2014, vol. 92, pp. 183-189. 
[30] Saravanan, D. UV protection textile materials, In: AUTEX Research Journal, 2007, vol. 7, issue 1, pp. $53-62$.

[31] Akaydın, M., İkiz, Y., Kurban, N. S. Pamuklu Örme Kumaşlarda UV Işınlarının Geçirgenliğinin Ölçümüve Değerlendirilmesi, In: Tekstilve Konfeksiyon, 2009, vol. 3, pp. 212-217.

[32] Ataşer, H.O. Amorf Silika Seramiklerinin Andaluzit Katkısıyla Sinterlenmeve Mekanik ÖzelliklerininIncelenmesi, İstanbul Teknik Üniversitesi, In: Fen Bilimleri Enstitüsü, Yüksek Lisans Tezi, İstanbul, 2010, 55 p.

\section{Authors:}

KADRI AKÇALI ${ }^{1}$

MELIHA OKTAV BULUT ${ }^{2}$

${ }^{1}$ Bartın University, Ulus Vocational School, Department of Textile, Clothing, Footwear and Leather, 74100, Bartın, Turkey

${ }^{2}$ SuleymanDemirel University, Engineering Faculty, Department of Textile Engineering,

32100, Isparta, Turkey

e-mail: akcali@bartin.edu.tr; oktavbulut@sdu.edu.tr

Corresponding author:

KADRI AKÇALI

e-mail: akcali@bartin.edu.tr

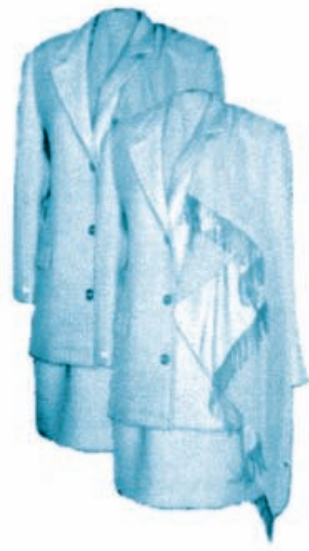

